\title{
Sociobiology
}

SHORT NOTE

\section{Parasitoids of Polistes myersi Bequaert, 1934 (Vespidae, Polistinae)}

\author{
D Mayorga-Ch, CE SARMiento
}

Instituto de Ciencias Naturales, Universidad Nacional de Colombia, Bogotá D.C., Colombia

\section{Article History}

\section{Edited by}

Marcel Hermes, UFLA, Brazil

Received 07 April 2020

Initial acceptance 20 May 2020

Final acceptance 08 June 2020

Publication date 30 September 2020

\section{Keywords}

Neotropics; Eulophidae; Signiphoridae;

Trigonalidae; Tachinidae; Xenidae.

\section{Corresponding author}

Carlos Sarmiento

Carrera 30, № 45-03. Edificio 425

oficina 303, Bogotá, Colombia.

E-Mail: cesarmientom@unal.edu.co

\begin{abstract}
s
Information about parasitoids of neotropical vespids is scarce. Parasitoids collected from 43 colonies of Polistes myersi Bequaert, 1934 and one of Polistes erythrocephalus Latreille, 1813 are reported from an Andean region of Colombia. Colony parasitism rates in P. myersi ranged from $35 \%$ to $57 \%$, being higher in colonies with more cells; however, the number of parasitized colonies did not differ when considering the mean number of adult wasps (8.2 vs. 8.1 respectively). Parasitoidism ranged from one up to four species per colony. P. myersi parasitoids were: Seminota laeviceps (Cresson, 1879) (Trigonalidae); Signiphora polistomyiella Richards, 1935 (Signiphoridae); Elasmus polistis Burks, 1971 (Eulophidae, Elasminae); and a new species of Xenos (Strepsiptera, Xenidae). The latter three are first records for Colombia. $P$. myersi and $P$. erythrocephalus are the first host reports for the trigonalid S. laeviceps. We also report an unknown Tachinid fly species of the tribe Blondeliini attacking $P$. myersi.
\end{abstract}

Social wasps are excellent predators (Elisei et al., 2010; Raveret Richter, 2000), however, are prey of other insects too as considerable resources are stored in their nests. There are many parasitoids of Polistes species, including Lepidoptera (Gelechiidae, Crambidae, Cosmopterigidae, Tineidae, and Pyralidae (Strassmann, 1981; Yamane, 1996)), Strepsiptera (Xenidae), Diptera (Phoridae, Sarcophagidae, and Tachinidae (Somavilla et al., 2015; Zeegers et al., 2014; Benadé et al., 2014)), and Hymenoptera (Pteromalidae, Chalcididae, Eulophidae, Torymidae, Ichneumonidae, Trigonalidae, Mutillidae, and even Vespidae itself (Benadé et al., 2014; Somavilla et al., 2015; Hodges, 2003; Whiteman \& Landwer, 2000; Gumovsky 2007; Silva-Filho 2007; Kozyra et al., 2014; Kudo et al., 2014; Madden et al., 2010; de Souza Tavares et al. 2013)).

Polistes myersi Bequaert, 1934 is found from Panamá to Venezuela (Richards, 1978). Their nests, of up to 100 cells, are found in perturbed habitats (Cubillos \& Sarmiento, 1996; London \& Jeanne, 2000), however, little is known about its biology and its relationships with predators and parasitoids. Here we report several parasitoid species of this wasp.
A total of 43 colonies with either late instar wasp larvae or pupae were collected from Fusagasugá, Cundinamarca, Colombia $\left(4^{\circ} 18^{\prime} 996^{\prime \prime} \mathrm{N}, 74^{\circ} 26^{\prime} 475^{\prime}\right.$ W, $\left.1309 \mathrm{~m}\right)$ in May and October 2017, and in August 2019. Each colony was established in transparent PVC cages $(25 \times 16 \times 16 \mathrm{~cm})$ and stored in a rearing chamber $\left(28{ }^{\circ} \mathrm{C}, 44 \% \mathrm{RH}, 12 / 12 \mathrm{~h}\right.$ photoperiod). Colonies had access to water and a mixture of water, honey, and pollen ad libitum. Depending on the colony size either one or two late instar larvae of Galleria mellonella Linnaeus, 1758 (Pyralidae) were offered every other day. Colonies increased their size and their larvae reached adulthood or even started new colonies.

Colonies were checked daily and emergent parasitoids were preserved in ethanol $96 \%$; these were identified using appropriate keys and help from specialists: For Hymenoptera the following references: Fernandez and Sharkey (2006), Burks (2019), Subba Rao (1974), Carmean and Kimsey (1998), and the following contacted specialists: D. Carmean, R. Burks, J. Wooley, and A. Dal Molin. For Strepsiptera the specialist Jerry Cook, (Sam Houston Natural History Collections). And 
for Diptera the specialist Juan Manuel Perilla (Wright State University). Parasitoids of a single incidental colony of Polistes erythrocephalus Latreille, 1813 are also reported. Specimens were deposited in the Instituto de Ciencias Naturales (ICN), Universidad Nacional de Colombia, Bogotá (Catalogue numbers Table 1).

A total of 19 colonies were infected by parasitoids; parasitism ranged from $35 \%$ to $57 \%$. Parasitized nests were larger than non-parasitized ones (average cell number 64 vs 38 respectively, Table 1). However, the mean number of adult females did not differ between parasitized and non-parasitized colonies (8.2 vs. 8.1 respectively, Table 1 ).

The following parasitoid species of $P$. myersi colonies are reported: Xenos n. sp. (Strepsiptera, Xenidae); Elasmus polistis Burks, 1971 (Hymenoptera, Eulophidae); Signiphora polistomyiella Richards, 1935 (Hymenoptera, Signiphoridae); Seminota laeviceps (Cresson, 1879) (Hymenoptera, Trigonalidae), and an unknown fly (Diptera, Tachinidae, Blondeliini) (Fig 1). Except for Xenos n. sp. all other parasitoids were collected during two or the three field trips.

Table 1. Characteristics of the parasitized nest of Polistes myersi where these parasitoids emerged (Mean \pm SD). *As some nests harbor more than one parasitoid species, the number of nests will not add up. ${ }^{\wedge}$ Museum collection number.

\begin{tabular}{lccc}
\hline \multirow{2}{*}{ Parasitoid species } & \multirow{2}{*}{ Infected nests* $^{*}$} & \multicolumn{2}{c}{ Nests characteristics } \\
\cline { 3 - 4 } Signiphora polistomyiella (ICN 101081)^ & 9 & $54.3 \pm 57.8$ & \# Females \\
Elasmus polistis (ICN 101078) & 8 & $71.3 \pm 57.0$ & $9.1 \pm 9.2$ \\
Blondeliini sp. (ICN 101079) & 7 & $45.1 \pm 16.3$ & $6.0 \pm 3.7$ \\
Seminota laeviceps (ICN 101080) & 3 & $60.3 \pm 51.9$ & $11.3 \pm 16.3$ \\
Xenos n. sp. (ICN 101082) & 1 & 72 & 13 \\
Non-Parasitized & 24 & $38.0 \pm 23.7$ & $8.2 \pm 5.9$ \\
\hline
\end{tabular}
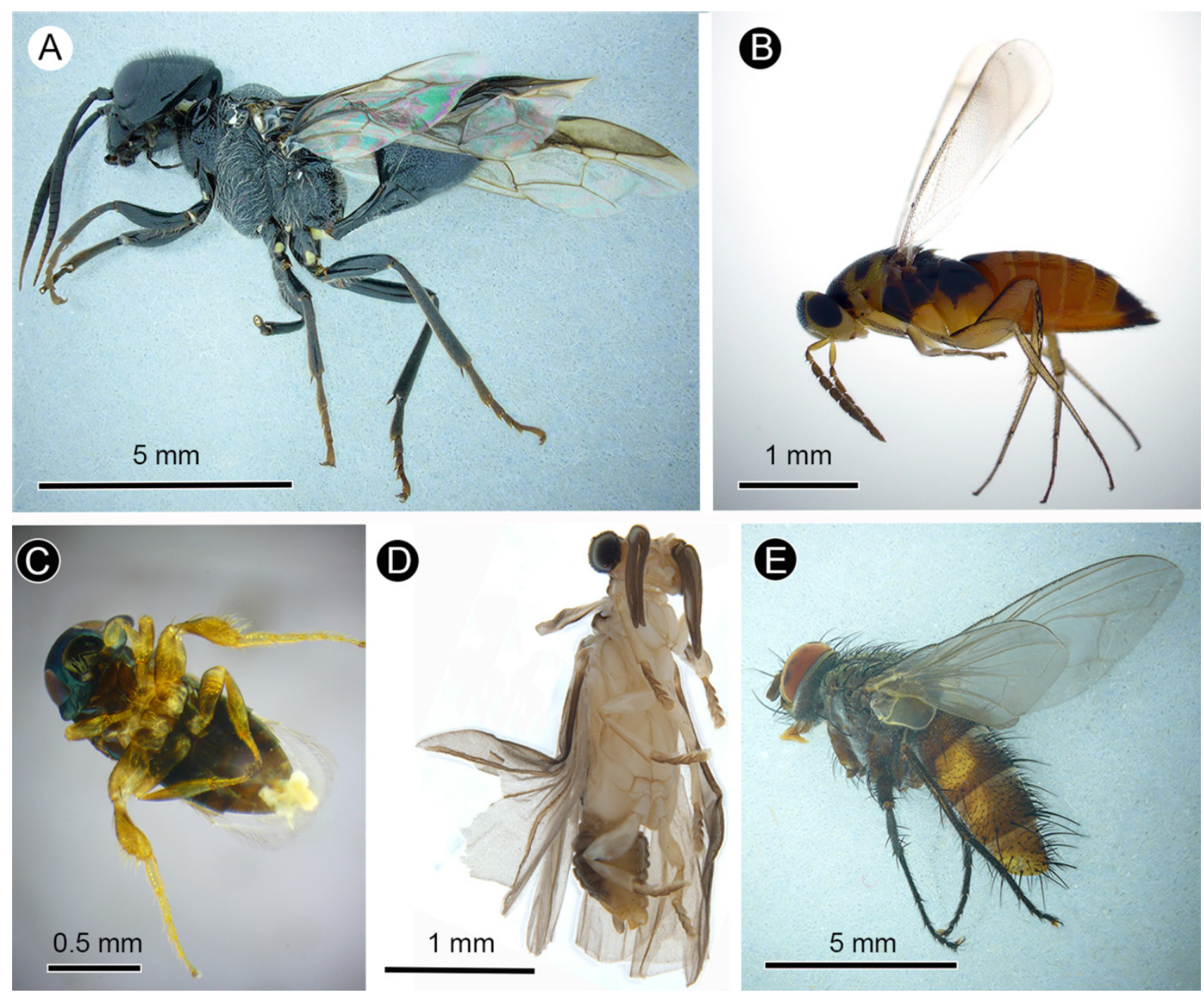

Fig 1. Habitus of the parasioids reported in the colonies of Polistes myersi and Polistes erythrocephalus. (A) Seminota laeviceps, (B) Elasmus polistis, (C) Signiphora polistomyella, (D) Xenos n. sp, and (E) Blondellini. 
From most of the colonies a single parasitoid species was obtained, with the following exceptions: two colonies with S. polistomyiella and E. polistis, one colony with E. polistis and a Blondeliini fly, and one colony with $S$. polistomyiella and a Blondeliini fly, one colony with S. polistomyiella, E. polistis and a Blondeliini fly, and one colony with S. polistomyiella, E. polistis, Xenos n. sp. and a Blondeliini fly. The number of parasitoids per colony could be higher as several of them are known hyperparasitoids. Below we give an account of the taxa recorded:

Elasmus (Eulophidae) is known as parasitoid of multiple taxa including Diptera, Lepidoptera and Hymenoptera families such as Braconidae, Ichneumonidae, and Vespidae (Askew et al., 1997; Gumovsky et al., 2007; Krombein, et al., 1951). It is also hyperparasitoid of Diptera (Noyes, 2019). Elasmus polistis is reported from Brazil, India, Germany, Mexico, U.S.A. and the Virgin Islands (Burks, 1971; Dorfey \& Köhler, 2011; Noyes, 2019), this is the first report for Colombia.

Signiphora polistomyiella (Signiphoridae) is parasitoid of Blondeliini (Tachinidae, Diptera) (De Santis, 1981) and hyperparasitoid of Vespidae such as Polistes pacificus and Mischocyttarus surinamensis (Vesey-Fitzgerald 1938). Nine colonies of this study had $S$. polistomyiella parasitoids. $S$. polistomyiella is reported from Peru and Trinidad and Tobago (Subba Rao, 1974), this is the first report for Colombia.

Seminota (Trigonalidae) is a hyperparasitoid genus of several Vespidae genera (Carmean \& Kimsey, 1998; Somavilla, 2015; Weinstein \& Austin, 1991). However, Santos and Noll (2013) suggest that primary parasitoidism may also occur. The genus has been reported in several countries of the Neotropics (Carmean \& Kimsey, 1998; Smith, 2012; Santos \& Noll 2013) but this is the first report for Colombia. To our knowledge, this is the first record of hosts for Seminota laeviceps, wich includes $P$. myersi and Polistes erytrocephalus.

Xenos, (Xenidae) as indicated by Cook's (2019) catalogue, is a widely distributed and known parasitoid of vespids (Kathirithamby, 2012; Cook, 2019). It was reported from Colombia as parasitoid of Polistes erythrocephalus (Girón, 2006). The specimen from our study belongs to a new species (Cook pers. comm.) under description.

The Tachinidae fly recorded belongs to the tribe Blondeliini. Unfortunately, there are no thorough taxonomic studies on this tribe for the neotropics. Consequently, no more accurate identification is possible. Blondeliini is a tribe with global distribution (Fuentes, unpub.). They are parasitoids of Lepidoptera, Coleoptera, and the Hymenoptera families Argidae Tenthredinidae, Braconidae and Vespidae (Zeegers, 2014; Guimaraes, 1977).

The number of parasitized colonies of $P$. myersi (average 44\%) was very high compared to other Polistes species. Hodges et al. (2003) reported a parasitism rate of $23 \%$ out of 303 studied nests for Polistes metricus in the USA. Keeping and Crewe (1983) reported five colonies of Belonogaster juncea and B. petiolata parasitized out of 63 colonies sampled in South Africa. The only higher record of parasitism rate than the present study was found in a small study with seven out of ten sampled colonies of Polistes dorsalis; these were parasitized by Elasmus polistis in the USA (Macom \& Landolt, 1995). The location of $P$. myersi in a highly disturbed area could explain these numbers.

\section{Acknowledgements}

The authors thank R. Burks, D. Carmean, J. Perilla, D. Benda, J. Cook, J. Wooley and A. Dal Molin for their help identifying the specimens. Acknowledge to Casa Buenos Aires, for their hospitality during the field trips, as well as the editor and the anonymous reviewers for their careful reading of the manuscript. This project was funded by the Vicerrectoría of the Universidad Nacional de Colombia grant number Hermes 34846.

\section{Authors Contribution}

Daniela Mayorga-Ch: Field work, data collection and analysis, writing paper. Carlos E. Sarmiento: Project design, field work, writing paper.

\section{References}

Askew, R.R., Segade, C., Blasco-Zumeta, J. \& Pujade, J. (1997). Species of Elasmus Westwood, 1833 (Hym., Chalcidoidea, Elasmidae) found in the lberian peninsula. Miscellània Zoològica, 20: 39-43.

Beaquert, J.C. (1934). Color variation in the South American social wasp, Polistes versicolor (Olivier) (Hymenoptera, Vespidae). Revista de Entomologia, 4: 147-157.

Benadé, P.C., Veldtman, R., Samways, M.J., Roets, F. (2014). Rapid range expansion of the invasive wasp Polistes dominula (Hymenoptera: Vespidae: Polistinae) and first record of parasitoids on this species and the native Polistes marginalis in the Western Cape Province of South Africa. African Entomology, 22: 220-225. doi: 10.4001/003.022.0104

Burks, B.D. (1971). A North American Elasmus parasitic on Polistes (Hymenoptera: Eulophidae). Journal of the Washington Academy of Sciences, 61: 194-196.

Burks, R.A. (2019). Key to the Nearctic genera of Eulophidae, subfamilies: Entedoninae, Euderinae, and Eulophinae (Hymenoptera: Chalcidoidea). Available from: https:// faculty. ucr.edu/ heraty/Eulophidae/index.html (accessed 21 September 2019)

Carmean, D. \& Kimsey, L. (1998). Phylogenetic revision of the parasitoid wasp family Trigonalidae (Hymenoptera). Systematic Entomology, 23: 35-76. doi: 10.1046/j.13653113.1998.00042.x

Cook, J.L. (2019). Annotated catalog of the order Strepsiptera 
of the World. Transactions of the American Entomological Society, 145: 121-267. doi: 10.3157/061.145.0202

Cubillos, W. \& Sarmiento C.E. (1996) Avispas sociales de Colombia. 269-348 In: Andrade G, Amat G, F Fernández (Eds.) Insectos de Colombia, estudios escogidos. Academia Colombiana de Ciencias Exactas, Físicas y NaturalesUniversidad Javeriana. Santafé de Bogotá, 541pp.

De Santis, L. (1981). Catálogo de los Himenópteros Calcidoideos de América al Sur de los Estados Unidos - Primer Suplemento. Revista Peruana de Entomología, 24: 1-38.

de Souza Tavares, W., Dias, A.M.P.M., de Souza, M.M., SilvaFilho, R., Serrão, J.E., \& Zanuncio, J.C. (2013). Pachysomoides sp. (Hymenoptera: Ichneumonidae: Cryptinae) Parasitizing Polistes versicolor (Hymenoptera: Vespidae) in Viçosa, Minas Gerais State, Brazil. Entomologica Americana, 119: 80-85.

Dorfey, C. \& Köhler, A. (2011). First Report of Elasmus polistis Burks (Hymenoptera: Eulophidae) Recovered from Polistes versicolor (Olivier) (Hymenoptera: Vespidae) Nests in Brazil. Neotropical Entomology, 40: 515-516. doi: 10.1590/S1519-566X2011000400019

Elisei, T., Nunez, VJ., Junior, CB., Junior AJF. \& Prezoto F. (2010). Uso da vespa social Polistes versicolor no controle de desfolhadores de eucalipto. Pesquisa Agropecuária Brasileira, 45(9), 958-964. doi: 10.1590/S0100-204X2010000900004

Fernández, F. \& Sharkey, M.J. (2006). Biología y diversidad de Hymenoptera. In: Fernández, F. \& Sharkey, M.J. (Eds.), Introducción a los Hymenoptera de la región neotropical. Sociedad Colombiana de Entomología y Universidad Nacional de Colombia, Bogotá D.C., pp. 93-113.

Guimaraes, J.H. (1977). Host-parasite and parasite-host catalogue of South American Tachinidae (Diptera). Arquivos de Zoologia, 28: 1-131.

Girón, J. (2006). Observación de Strepsiptera (Stylopidae) sobre avispas papeleras Polistes erythrocephalus Latreille en Cali. Boletín del Museo de Entomología de la Universidad del Valle, 7: 32-33.

Gumovsky, A., Rusina, L. \& Firman, L. (2007). Bionomics and morphological and molecular characterization of Elasmus schmitti and Baryscapus elasmi (Hymenoptera: Chalcidoidea, Eulophidae), parasitoids associated with a paper wasp, Polistes dominulus (Vespoidea, Vespidae). Entomological Science, 10: 21-34. doi: 10.1111/j.14798298.2006.00195.x

Hodges, A.C., Hodges, G.S. \& Espelie, K.E. (2003). Parasitoids and Parasites of Polistes metricus Say (Hymenoptera: Vespidae) in Northeast Georgia. Annals of the Entomological Society of America, 96: 61-64. doi: 10.1603/0013-8746(2003)096[0061:PAPOPM]2.0.CO;2

Kathirithamby, J. (2012). Strepsiptera. In: Rafael, J.A.,
Rodrigues de Melo, G.A., Barros de Carvalho, C.J., Aparecida Casari, S. \& Constantino, R. (Eds.), Insetos do Brazil: Diversidade e Taxonomia I. Holos Editora, Ribeirão Preto, pp. 745-752.

Keeping, M.G. \& Crewe, R.M. (1983). Parasitoids, commensals and colony size in nests of Belonogaster (Hymenoptera: Vespidae). Journal of the Entomological Society Slk Africa, 46: 309-323.

Kozyra, K.B., Baraniak, E., \& Tyczewska, M.J. (2014). Parasitoids of the paper wasp Polistes nimpha (Hymenoptera: Vespidae) in Poland. Zoology and Ecology, 24: 58-61. doi: $10.1080 / 21658005.2014 .882608$

Krombein, K.V., Muesebeck, C.F., Townes, H. (1951). Hymenoptera of America north of Mexico: synoptic catalog. Washington, D.C. : Dept. of Agriculture, 1436pp.

Latreille, P.A. (1813). Insectes de l'Amérique équinoxiale recueillis pendant le voyage de Humboldt et Bonpland, Seconde partie. In: Smith, C.J. \& Gide, E.C. (Eds.) Voyage de Humboldt et Bonpland, Deuxième Partie. Observations de Zoologie et d'Anatomie Comparée. Paris, France. p. 96.

Linnaeus, C. (1758). III. Lepidoptera. In: Salvii, L. (Ed.), Systema Naturae per Regna Tria Naturae, secundum classes, ordines, genera, species, cum characteribus, differentiis, synonymis, locis Tomus I. Editio Decima, Reformata. Holmiae: Impensis Direct, Stockholm, pp. 458-542. doi: 10.5962/bhl.title.542

London, K.B., Jeanne R.L. (2000). The interaction between mode of colony founding, nest architecture and ant defense in polistine wasps. Ethology, Ecology and Evolution, 12: 13-25. doi: 10.1080/03949370.2000.9728440

Macom, T.E. \& Landolt, P.J. (1995). Elasmus polistis (Hymenoptera: Eulophidae) recovered from nests of Polistes dorsalis (Hymenoptera: Vespidae) in Florida. Florida Entomologist, 78: 612-615. doi: 10.2307/3496048

Madden, A.A., Davis, M.M., \& Starks, P.T. (2010). First detailed report of brood parasitoidism in the invasive population of the paper wasp Polistes dominulus (Hymenoptera, Vespidae) in North America. Insectes sociaux, 57: 257-260. doi: 10.1007/s00040-010-0079-0

Noyes, J.S. (2019). Universal Chalcidoidea Database. World Wide Web electronic publication. http://www.nhm.ac.uk/ chalcidoids. (accessed date: 29 May, 2020).

Raveret Richter, M. (2000). Social Wasp (Hymenoptera: Vespidae) Foraging Behavior. Annual Review of Entomology, 45: $121-150$

Richards, O.W. (1935). Two new parasites of aculeate Hymenoptera from Trinidad. Proceedings of the Royal Entomological Society of London. Series B, 4: 131-133. doi: 10.1111/j.1365-3113.1935.tb00575.x

Richards, W. (1978). The Social Wasps of The Americas. 
London: British Museum (Natural History), 585p

Santos, E.F. \& Noll, F. B. (2013). Biological Notes on the Parasitism of Apoica flavissima Van der Vecht (Hymenoptera: Vespidae) by Seminota marginata (Westwood) (Hymenoptera: Trigonalidae): Are Social Paper Wasps Primary or Secondary Hosts of Trigonalidae? Sociobiology, 60: 123-124.

Silva-Filho, R., Rodrigues Cassino, P.C., Marques, O.M., Penteado-Dias, A.M., Rodrigues, W.C., \& Zanuncio, J.C. (2007). Parasitoids of Polistes lanio lanio (Hymenoptera: Vespidae) larvae in the municipality of Seropédica, Rio de Janeiro State, Brazil. Sociobiology, 50: 1191-1198.

Smith, D.R., Janzen, D.H., Hallwachs, W. \& Smith, M.A. (2012). Hyperparasitoid wasps (Hymenoptera, Trigonalidae) reared from dry forest and rain forest caterpillars of Area de Conservación Guanacaste, Costa Rica. Journal of Hymenoptera Research, 29: 119-144. doi: 10.3897/jhr.29.3233

Somavilla, A., Schoeninger, K., Carvalho, A.F., Menezes, R.S.T., Del Lama, M.A., Costa, M.A. \& Oliveira, M.L. (2015). Record of Parasitoids in nests of social wasps (Hymenoptera: Vespidae: Polistinae). Sociobiology, 62: 9298. doi: 10.13102/sociobiology.v62i1.92-98

Strassmann, J.E. (1981). Parasitoids, predators, and group size in the paper wasp, Polistes exclamans. Ecology, 62: 1225-1233. doi: 10.2307/1937287

Subba Rao, B.R. (1974). The genera of Signiphoridae
(Hymenoptera) with description of a new genus. Bulletin of Entomological Research, 64: 525-531. doi: 10.1017/ S0007485300035835

Vesey-Fitzgerald, D. (1938). Social Wasps (Hym. Vespidae) From Trinidad, With A Note On The Genus Trypoxylon Latreille. Transactions of the Royal Entomological Society of London, 87: 181-191. doi: 10.1111/j.1365-2311.1938.tb00093.x

Weinstein, P. \& Austin, A.D. (1991). The host relationships of trigonalyid wasps (Hymenoptera: Trigonalyidae), with a review of their biology and catalogue to world species. Journal of Natural History, 25: 399-433. doi: $10.1080 / 00222939100770281$

Whiteman, N.K. \& Landwer, B.H. (2000). Parasitoids reared from Polistes (Hymenoptera: Vespidae: Polistinae) nests in Missouri, with a state record of Elasmus polistis Burks (Hymenoptera: Elasmidae). Journal of the Kansas Entomological Society, 73: 186-188.

Yamane, S. (1996). Ecological factors influencing the colony cycle of Polistes wasps. In Turillazzi, S. \& West-Eberhard, M.J. (Eds.), Natural history and evolution of paper-wasps (Vol. 400). Oxford: Oxford University Press., USA Pp. 75-97.

Zeegers, T. (2014). Tachinidae (Diptera) reared from Ropalidia nests (Hymenoptera: Vespidae) from Madagascar, with two new species of Anacamptomyia. Tijdschrift voor Entomologie, 157 (2-3): 95-103. doi: 10.1163/22119434-00002041

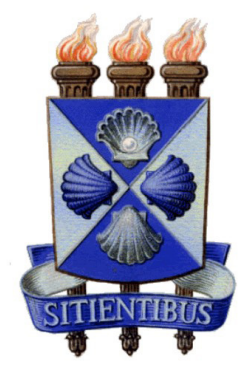

